UDC 9112:[504.5:630*1](671.1-14)«20»

DOI: $10.18524 / 2303-9914.2019 .1(34) .169711$

Theophilus Mukete Nayombe Moto, Post Graduate Student (Cameroon)

Odessa I. I. Mechnikov National University,

Department of Physical Geography and Environmental Sciences,

Shampansky lane, 2, Odessa, 65058, Ukraine

muketem2002@yahoo.com

\title{
MODERN THREATS TO NATURAL FOREST LANDSCAPES \\ IN THE SOUTH WEST REGION OF CAMEROON: THE CASE OF THE CAMEROON MOUNTAIN
}

The article reviews the natural and anthropogenic factors that have influenced the rapid deforestation and degradation of the forest landscapes of the Mount Cameroon ecosystem. One of the greatest riches of Cameroon in addition to mineral exploitation is the moist evergreen equatorial forest. This forest ecosystem is known for its high degree of speciation, biological diversity and very high biological productivity in the Guinea-Congolese regional zone of endemism. However, this ecosystem has not been very stable over the past decades. The forest has witnessed significant damages due to some natural and anthropogenic activities. These activities range from unsustainable agricultural practices, uncontrolled and spontaneous growth of infrastructures. This has led to the continuous degradation of the forest cover to the extent that there is a complete disappearance of vegetation cover. This has serious consequences on the soils through accelerated erosion and leaching, displacement of wild animals, destruction of microorganisms, accelerated dryness of springs and small streams, thereby, worsening the impact of climate change.

The study therefore, analyzes the vegetation structure of the Cameroon mountain (mangrove, lowland/foot-hills and montane/afromontane forest landscapes) and reviews the natural and anthropogenic factors that impact the forest landscape. Furthermore, analysis of the dynamics, transformation and changes within a period of 50 years (1965-2015) will equally be studied.

The methodology used in this work is descriptive, analytic and comparative. Secondary data from satellite images were used to study the land use dynamics in 1978,2000 and 2015

The results of our findings revealed that a combination of natural and human factors has reduced the forest landscape of this eco-region to about $79 \%$. But man in particular has raped huge tracks of forest landscapes for his selfish economic gains without making any commensurate effort for their sustainability and conservation. It is however obvious that such irrational use of nature takes place against the background of the lack of professional organization of the territory and programs for the use of forest resources. The rational use, protection and preservation of forests and forest landscapes is the basis for the harmonious development of the natural environment, which is based on modern scientific and practical structural and geographical research. This study therefore, proposed some urgent environmental strategies to rescue this eco-region from further degradation.

Keywords: natural forest landscapes, mount Cameroon, south-west region of Cameroon. 


\section{INTRODUCTION}

Problem statement. Much research has been done on the causes and impacts of forest degradation in Cameroon. But it is rather unfortunate that these studies have been so generalized in their analysis without focus on a particular ecosystem. The result of their findings is based on estimates without practical field measurements. Failure of these studies to carry out a detail analysis based on practical constructive geography that show the transformation, dynamics and changes in vegetal cover has made it difficult for policy makers to understand the gravity of forest degradation in Cameroon. Worst of all is the fact a handful of these authors who have attempted to study forest dynamics have only emphasized on the causes of forest degradation without proposing adaptive environmental strategies for their protection and rational use.

Owing to the fact that the Mount Cameroon forest is a peculiar ecosystem which provides a biological mosaic that contributes to extremely high diversity in the Guineo-Congolian regional area of endemism, and it is regarded as one of the main Pleistocene refugia postulated for Africa with around 4,000 higher plant species and about 50 of these are endemic to Mount Cameroon (Fig. 1). This was the last area in Africa where natural vegetation remained unbroken from lowland forest at sea level to the sub-alpine grassland at the summit. But today it is rather unfortunate that the rate at which this forest ecosystem is being hewed down for various reasons of developments leave much to be desired.

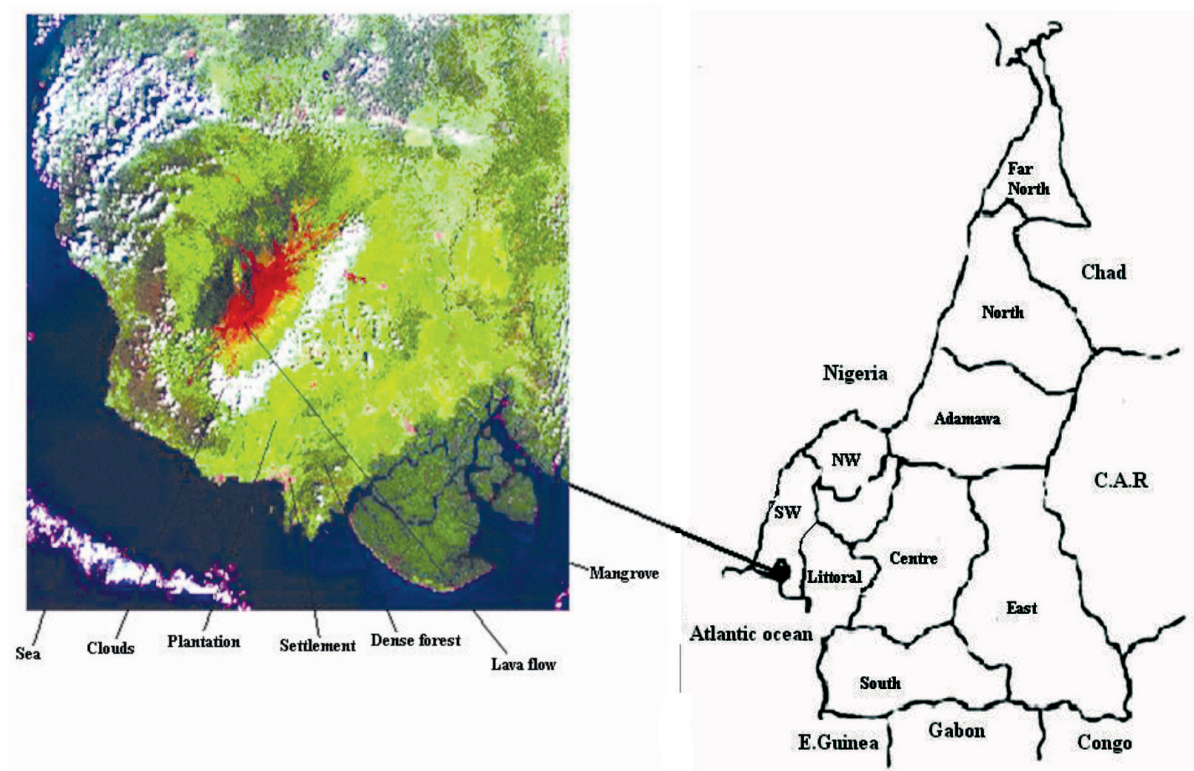

Fig. 1. Map of the study area projected through satellite image on the left (Mount Cameroon ecosystem in the south west region) and (the map of Cameroon) right 
Natural and human activity has had a profound impact on the natural forest landscapes of this massif to the extent that the high intensity of these phenomena has created cultural landscapes which have swallowed up the natural ones thereby alternating the balance sheet within the natural ecosystem in this region.

Literature review. It is worth mentioning that in Cameroon there is insufficient and reliable information about forest cover and forest resources. No official data and temporal series exist about the extent of forest cover. These notwithstanding a handful of studies have attempted some tentative research to examine the forest landscape in a generalized manner. Their results have contributed fully or partially to the realisation of this article.

Some of the most renowned studies include the works of [26], who viewed mountainous environments as example of less recognized regions with critical types of biodiversity where mountain dwellers live at the economic margins on forestdependent livelihood activities [5]. With increasing demographic pressure and access to markets, the sustainability of the forests and therefore local livelihood are threatened by degradation, [4]. In this light, [15] concluded that conservation approaches that ignore local livelihoods are doomed to fail.

The research of [14] affirms that Mountain ecosystems comprise between 10000 to 15000 different species of plants and animals. Such a situation is explained by altitudinal elevation which produces different climatic bands. Also, [13, 29] confirms that the soils, fuana, flora as well as the level of precipitation vary from the foot of the mountain to the summit and from the windward side to the leeward side of the mountain.

The Mount Cameroon region falls in line with this generalized ecosystem known of its high endermism [11]. The past human activities caused considerable damage to the biological and physical environments, thus threatening the survival of the ecosystem. According to $[19,21]$ it was for this reason that the MCP (Mount Cameroon Project) was established to check the current spiralling system of self destruction. In line to the view [7] concluded that the unsustainable use of natural resources and biodiversity loss has of the last decade has not been given great attention by policy-makers, international institutions and scholars.

According to [28], in most of the tropical states, the trend of biodiversity loss is above all other factors, more or less influenced by institutional weaknesses or failures. This according to $[20,22]$ the uncontrolled use of wildlife products is contributing to species extinction and loss of biological diversity, the yearning for tropical hardwoods and fibre by developed world, and the growing human population even without accompanying economic development, place increasing demand on natural resources and ecosystem process that are already improvished and stressed [9].

Furthermore, the biodiversity upon which human survival depends is still poorly known in the study area [21]. It is for this reason that [7] concluded that poor governance is a major determinant to unsustainable use of resources. This 
tendency has more or less encouraged local people to prey on natural resources, which have affected the biodiversity and forest ecosystems in general, a view supported by $[23,24]$.

Since man is placed at the centre of the environment, it is either he nurtures or he destroys it. But looking at a critical view in our study area, [25], man has failed to play his fundamental role as a conservator. This is the reason why we are witnessing faster rates of forest disappearance today. The slash and burn methods of farming according to [6] do not give room for regeneration as it destroys the bacteria and other soil components. Besides the actual cutting down of the forest there is no possibility for regrowth. Also the method of bush fallowing still practiced in some communities especially as concerns food crops for sale like cassava and melon (egussi) calls for the clearance of forest for new farms when fertility is exhausted [21].

According to $[3,18]$ debt-induced poverty has caused the country to exploit natural resources in the most profitable but least sustainable way. Worst still, according to [12] those responsible for managing wildlife and protected area are poorly paid, have insufficient opportunities for advancement, lack specialized training, and have low prestige. As concerns deforestation statistics [30], the exact rate of deforestation in Cameroon is unknown, as much of what exists is based on estimates.

On a general note, deforestation rate estimates in Cameroon range from 80,000 to 200,000 hectares per year [27]. According to [8] the annual average deforestation rate in Cameroon for the $1980-1995$ period was $0.6 \%$ or a loss of close to 2 million ha [27]. From 1990-2000 the rate reportedly rose to $0.9 \%$ and reached $1 \%$ between 2000 and 2005, [8]. The FAO figures from 2005 to 2010 show a loss of around 200,000 ha per year, which corresponds to about $1 \%$ of the forest cover, which means a decline in forest area from 22 million ha to 20 million ha.

Previously unresolved questions this paper is dedicated. The complexity of forest types and their species over time in the mount Cameroon eco-region has remained a bewildering attribute of nature. This complex nature underlies the reasons for the highly diversified ecosystems and complex biodiversities. But the ecosystems have not remained stable as the forest ecosystems have been influenced by a number of factors which may range from natural causes to anthropogenic activities as man over historic time has manifested himself as a serious threat to the forest ecosystem.

The main drivers or threats to natural ecosystem in the Mount Cameron region can be attributed to natural and anthropogenic factors. The natural habitats of this eco-region have been seriously threatened and are being lost through conversion to agriculture, unsustainable exploitation of forest resources, illegal timber exploitation, fires from farmland, and the collection of firewood, construction materials and uncontrolled urbanization. Because volcanic rock produces good soils, there is considerable pressure to convert large forest areas to farmland.

The paper aims: This article analyses the distribution, structure and variability of forest landscapes in the Mount Cameroon ecosystem, and will establish forest landscape maps that will illustrate areas of anthropogenic influences and patterns 
of forest landscape formation. The altitudinal variation of vegetation on Mount Cameroon and analysis of the natural threats posed by the flow of hot fluid lava during volcanic eruptions will be studied.

A critically review of the diverse human activities on the slopes of the mountain will be carried out. The results of the analysis will be used as a guide to develop adaptive strategies for an optimal organization of economic activities, environmental protection and the sustainable use of natural resources in this region. On the basis of the above, a detail and practical study on the Mount Cameroon ecosystem will be documented. The study will form the basis that policy makers in south west region of Cameroon have to apply in order to efficiently manage forest, its resources and human habitation.

\section{DATA AND METHODS}

During the writing of this article we made us of primary and secondary sources of data collection. The primary source obtained information from field descriptions and measurements, while the secondary source dwelt with the results from office data processing and materials of scientific publications.

The GIS methods (GIS packages MapInfo Professional, Saga and Golden Software Suffer) helped us to obtain digital maps. Remote sensing methods of Earth remote sensing equally helped us to study the dynamics of forest landscapes for 1978, 2000 and 2015 vis-avis human activities on the slopes of the Cameroon Mountain. Comprehensive landscape methods were used to study the structure and dynamics of forest landscapes of the studied area. This data was analyzed in the form of tables, graphs and maps.

\section{RESULTS AND DISCUSSION}

The mount Cameroon eco-region provides a biological mosaic that contributes to extremely high diversity of endemism, and it is regarded as one of the main ecorefugia postulated for Africa. The massifs and surrounding foothills contain around 4,000 higher plant species and about 50 of these are endemic to Mount Cameroon (Fig. 1). But within the past 20-30 years the region has recorded significant damages to its ecosystems following the unsustainable use and over exploitation of natural resources. The mount Cameroon eco-region is located in latitude $3^{\circ} 37^{1}$ to $4^{\circ} 28^{1}$ $\mathrm{N}$ and from longitudes $8^{\circ} 58^{1}$ to $9^{\circ} 24^{1} \mathrm{E}$ of the prime meridian. For decades this ecosystem has remained one of the most productive in Cameroon. As the cultural landscapes continue to swallow the natural ones due to the high rate of anthropogenic alterations introduced by man in his quest for better socio-economic development, the balance sheet between natural existing systems have always been negative.

This region is characterized by a variety of distinct forest landscapes from the coastal lowlands to the peak of the mountain. The mount Cameroon region harbours diverse forest landscapes (Fig. 2). These include the mangrove forest landscape, the lowland and foothills forest landscape and the montane/afromontane forest 
landscapes. The montane and afromontane forest landscapes are sub- divided into the Sub-montane forest 800-1700 m, the Montane forest 1600-1800 m, the Montane Shrubs above $1800 \mathrm{~m}$, the Sub-alpine grassland (2000-3000 m) and the sub-Alpine prairie (2800-4095 m) to which a bare surface lava is added. Each of these vegetation sub-categories comprise of a mosaic of sub-variant plant communities.

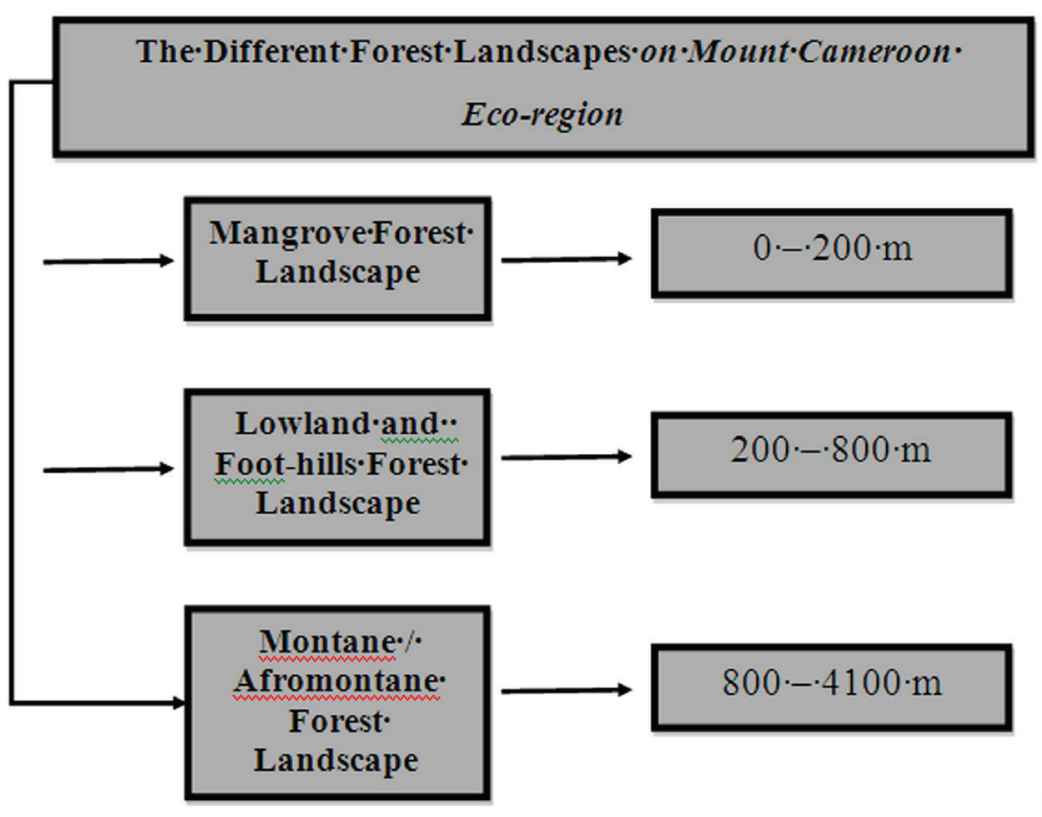

Fig. 2. The different forest landscapes on mount Cameroon volcano

The Mangrove Forest Landscape (0-200 m). The mangrove forests occupy the swampy zones of Tiko Creeks and ends at Kangue located at about $30-35 \mathrm{~km}$ in the south east of Buea at the foot of Mount Cameroon. It altitude never exceeds $200 \mathrm{~m}$ above sea level. These sites are noted to be the two of the thirty four fishing sites located within or adjacent to the 19,000 ha of mangrove forests in the Fako-Meme forest regio.n of Cameroon [19]. These mangrove forest landscapes are dominated by Rhizophora racemosa and Pandunus satabiei, Saccoglottis gabonensis, Andira inermis, Cynometra hankei, Coula edulis and Pycnanthus angolensis, and there is an exceptional abundance of Lophira alata [1,2]. $3 \mathrm{~m}$ and dbh $40 \mathrm{~cm}$.

Mangrove forests are extremely productive ecosystems that provide numerous goods and services both to the marine environment as well as to the in situ and ex situ communities.

The lowland and Foot Hills Forest $(200-800 \mathrm{~m})$. It is covered with equatorial evergreen forest (tropical rainforest) from which we can distinguish different alternations of vegetation with altitude. It should be noted that between $200-800 \mathrm{~m}$ 
above sea level, the natural forest vegetation has been cut down to create settlements, farms and plantations. This area has developed a sort of secondary forest. The lowland forest occurs inland of the coastal forest mainly between 200 and $800 \mathrm{~m}$ above sea level.

Table 1

The main Mangrove species in mount Cameroon eco-region

\begin{tabular}{|l|c|}
\hline \multicolumn{1}{|c|}{ Scientific name } & Common name \\
\hline Acrostichum aureum & Golden leather fern \\
\hline Avicennia germinans & Black mangrove \\
\hline Conocarpus erectus & Buttonwood mangrove \\
\hline Laguncularia racemosa & White mangrove \\
\hline Nypa fruticans & Mangrove/nypa palm \\
\hline Rhizophora harrosonii & Red mangrove \\
\hline Rhizophora mangle & Red mangrove \\
\hline Rhizophora racemosa & Red mangrove \\
\hline
\end{tabular}

The lowland forest surrounding Mount Cameroon is distinguished into three major forest types. These include the Atlantic Biafran lowland forest, the moist evergreen forest dominated by Caesalpiniaceae; important genera include Afzelia, Brachystegia, Cynometra, Didelotia, Gilbertiodendron, Julbernardia, Monopetalanthus and Paraberlinia and the Coastal forest dominated by onbangia alata and recent second growth forest. The region's original vegetation has been altered from thick rain forest to anthropogenic vegetations such as the palm and banana plantation's of the Cameroon Development Cooperation (CDC) and the man made vegetation such as the Limbe Botanical Garden.

The Montane/Afromontane Forest Landscape $(800-4095 \mathrm{~m})$. The montane landscape lies inland immediately after the Lowland forest Landscape. The zone starts from about 800-1700 $\mathrm{m}$ above sea level. Unlike the Lowland forest landscape, primary forest can be found at an altitude of $915 \mathrm{~m}$ (above Buea Town). The forest is immense, luxuriant and has a continuous canopy of leaves. It is dark and damp and has very thin undergrowth; this is because little or no sunlight ever reaches underneath.

This rainforest is the home for many animals like the elephants, the monkeys, the chimpanzees and many rodents. The forest extends up to an altitude of $1700 \mathrm{~m}$ above sea level and gives rise to savanna grassland vegetation.

The grass is much shorter and can be termed prairie from a height of 3000$3500 \mathrm{~m}$. We found five distinct vegetation belts on the volcano as one climbs up the mountain. The wealth of this region in terms of biodiversity is enormous with more 
than 250 species of trees, of these, 49 are endermic and 52 restricted to the Central African region Letouzey, 1985 [9, 16, 17].

By altitudinal variation of vegetation, we refer to the vertical layering of the different vegetation strata. This classification is done in accordance to the different heights to which their plants grow. The stratozones are inhabited by different plants and animals. This stratification is influenced by the life form of the plants, their size, branching and leaves which in a generalized manner is influenced by the vertical gradient of light.

The vegetation type equally influenced the human activity in the stratum. For example, at about $3000 \mathrm{~m}$ where we have savanna, the main human activity here is hunting. At the height of $1000 \mathrm{~m}$ where we have the lowland tropical forest it is very obvious that diverse human activities have if not raped the entire forest landscape, Fig. 3. We find a plethora of agro-industrial plantations, rapid expansion of infrastructures, subsistence agricultural practices, just to mention a few.

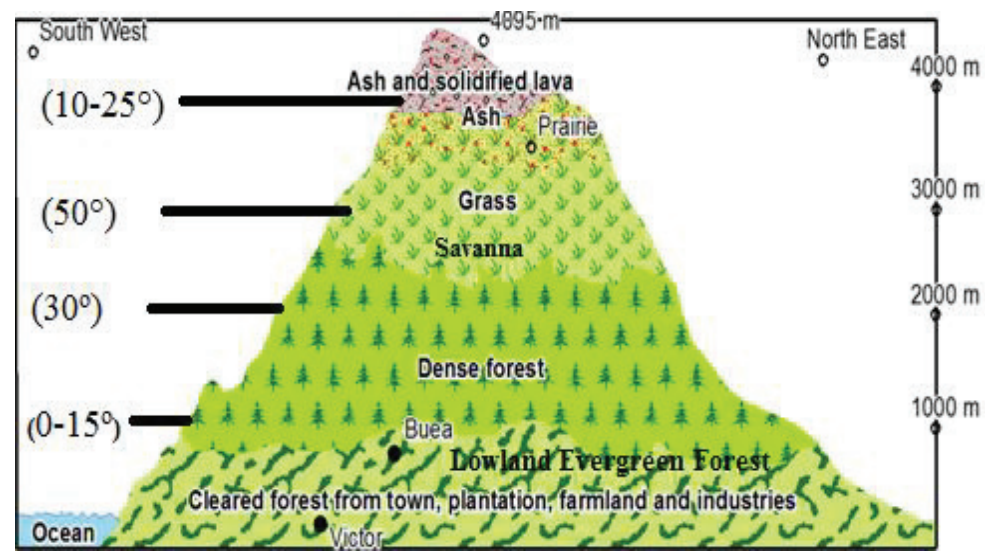

Fig. 3. Diagramatic Repesentation of the Vegetation Pattern on Mount Cameroon

The Lowland evergreen forest 200-800 m; the Sub-montane forest 800-1700 m; the Montane forest 1600-1800 m; the Montane Shrubs above $1800 \mathrm{~m}$; the Subalpine grassland (2000-3000 m); the Sub-Alpine prairie (2800-4095 m). To these can added bare surfaces of lava

The vertical classification of forest landscapes in the Mount Cameroon region depicts the different vegetation strata, the different species of trees, shrubs, herbaceous layers and forest floor. It is therefore very important for a more detail study to be carried out on the Mount Cameroon to make a careful inventory of the different plant species, their heights, the dbh and their canopy. This type of study will help forest planners to know the species and quantity of trees which need to protected or planted in degraded areas. 
Evidence from (Fig. 3), shows that the vegetation changes from the foot hills to the mountain top and the forest gives way to savanna and prairie due to the influence of very strong winds. The vegetation stratum is influenced by the slope gradient of the mountain, Fig. 3.

From the slope gradient $\left(0-15^{\circ}\right)$ we have the low land Biafran forest which covers the height from 0 to $1000 \mathrm{~m}$. The forest ecosystem here has been highly tempered for various purposes. Taking into consideration that the Mount Cameroon region is in its $3^{\text {rd }}$ stage of economic growth, urbanization and its concomitant problems of land scarcity, expansion of settlements, large agro-industrial plantations, and unsustainable agricultural practices are common vises that contributes to forest degradation. The fact that the forest-adjacent communities storm the forest on daily basis to secure their immediate needs only helps to aggravate the intensity of resource depletion.

The gradient increases to $\left(30^{\circ}\right)$ from the height of 1000 to $2000 \mathrm{~m}$. Human activities reduce with height on Mount Cameroon. Here we witness the dense tropical mountain forest in its natural stage with very insignificant foot prints.

From 2000 to $3000 \mathrm{~m}$ we have an escarpment $\left(50^{\circ}\right)$ gradient) savannah dominates. This is the steepest level of the mountain. At this level hunting becomes very vital. The only set-back is because this activity is carried out indiscriminately without respect of the animal husbandry law.

From $3000 \mathrm{~m}$ to the summit, the gradient reduces to 10 and $25^{\circ}$, there is prairie vegetation and steppe disappears with altitude to give way to lichens and mosses beyond $3800 \mathrm{~m}$.

The mount Cameroon volcano has been witnesses a drastic reduction in its forest landscapes as natural and anthropogenic forces continue to intertwine. The main natural threat in this region is volcanic eruption. Other threats with minor or insignificant impact include landslide and mudflow.

Threats from Volcanic Eruptions. Over the extreme arcs of Earth's history, areas have been deforested because continental drift has moved regions into climate types which are not supportive of forests. So, too, ancient deforestations can be recognized as being caused by volcanic eruptions and explosions and, more extensively, by basaltic lava flow covering hundreds of thousands of square kilometers. This is the case with mount Cameroon. This region has witnessed rampant eruptions and explosions of such basaltic lava flows covering vast areas previously occupied by forest. Their flows have been very uncompromising to the forest landscapes and their occurrences have been frequent in recent times.

For example, Mount Cameroon erupted thirteen times in the last 200 years, thus making it a very active volcano in West Africa. Mount Cameroon stands as a replica of volcanic mountains which send out hot lava that flows through the vents Fig. 4. This active volcano has been known to pose great threats not only to lives and properties but also to the natural environment within the region. These dangers result from lava flows, gas emissions, ash falls and mass flow of volcanic debris derived from the mountain flank or sector collapse. These natural disasters such as the recent Mount Cameroon volcanic eruption have been implicated in the Charing of forests. 


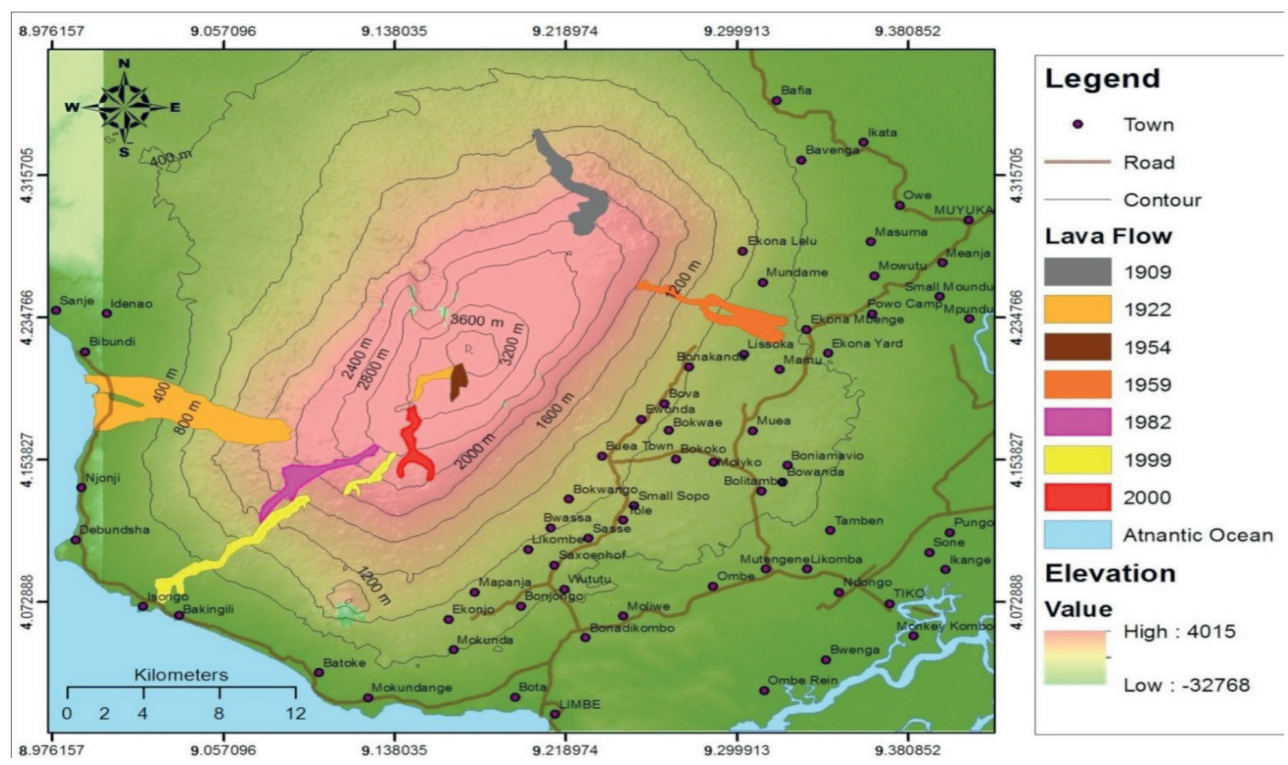

Fig. 4. Map showing the Different Lava Sites and their Eruption

Nature remains capricious and as usual, could «defy the predictions and make nonsense of the human mathematisation of sub-terranean geologic phenomena». Plantations of oil palms, vegetation to name just a few have been destroyed by advancing of hot basaltic lavas with very high temperatures. In addition to this, most of the animals in the region have been displaced; others are threatened and could even go into extinct. Human or forest safety through geological time cannot be guaranteed most especially in the inhabited eastern slopes of Mount Cameroon. To this effect, forest landscapes are threatened by constant volcanic eruptions on active volcanic mountains.

Anthropogenic Threats to Forest Landscapes on the Slopes of Mount Cameroon. Anthropogenic deforestation has been a significant imprint on landscapes of the Mount Cameroon eco-region for a very long time. Humans have become inexorably intertwined with deforestation. Some of the main human activities that have helped to rape the natural forest landscapes include unsustainable agricultural activities, uncontrolled agro-industrial plantations of palms, rubber and tea, spontaneous urban growth and uncontrolled population increase just to mentioned a few as epitomized in (Fig. 5).

With today's rapid increase in population, deforestation is of increasing concern. «Man has been endowed with reason, with the power to create, so that he can add to what he's been given. But up to now he hasn't been a creator, only a destroyer. Forests keep disappearing, rivers dry up, wild life's becomes extinct, the climate's ruined and the land grows poorer and uglier every day». 
The Mount Cameroon ecosystem is a replica of a High Conservation Value Forest (HCVF) under continuous menace caused by natural and human drivers. There are thus too many demands on the limited natural resource base [10]. Pointed out a similar view that as long as man lives on the natural resources, humanity is currently faced with the prospects of further development which evidently calls for an accelerated forest disappearance.

The over exploitation of these forest landscapes have yielded greater benefits to the forest-adjacent communities but the beneficiaries have not made commensurate investments in terms of their sustainability and adaptation to this wanton exploitation.

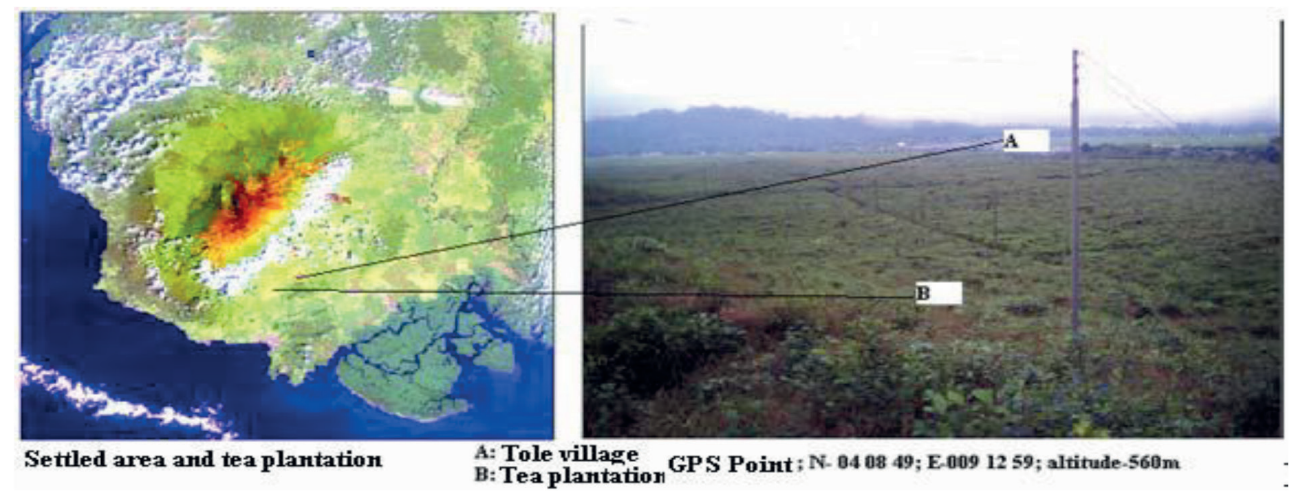

Fig. 5. Settlement and Tea Plantation at the height of $1000 \mathrm{~m}$

Human mismanagement of the biological resources, often stimulated by misguided economic policies and faulty institutions that enable the exploiters to avoid paying the cost of their exploitation has been the cause of such anarchical activities as displayed in Fig. 6. It is visible that at the height of $1000 \mathrm{~m}$, the eastern slopes of Mount Cameroon are being exploited as projected from satellite images.

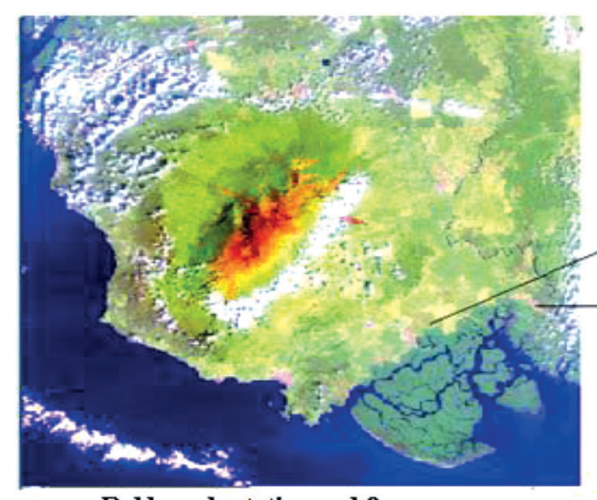

Rubber plantation and farms

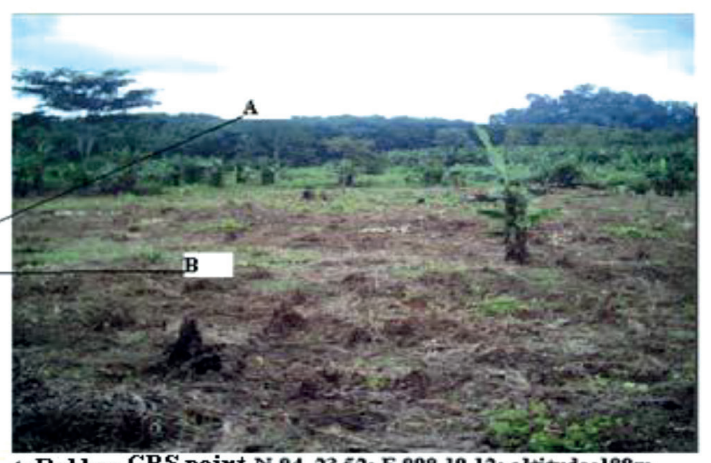

A:Rubber GPS point N-04 23 52; E-009 19 12; altitude:109m B:Farm

Fig. 6. Rubber Plantation and Farms at the height of $1000 \mathrm{~m}$ 
With such an anarchical exploitation of forest it only obvious that the mount Cameroon eco-region has undergone changes in its forest landscapes. These changes were studied with the use of satellite image interpretation in three separate periods, 1978, 2000 and 2015 as shown in (Fig. 7 and Table 2).

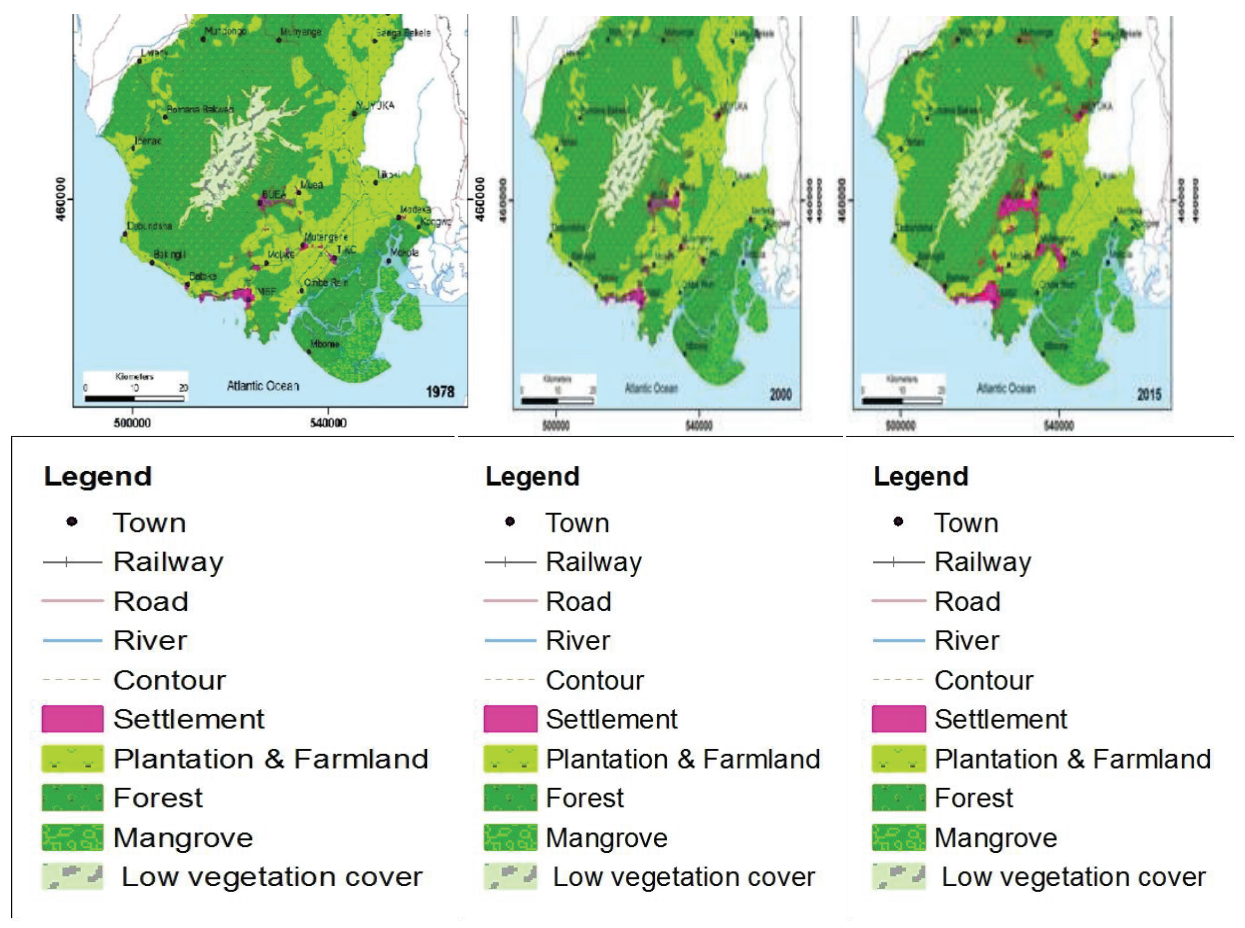

Fig. 7. Change of land-use pattern in the mount Cameroon eco-region (1978-2000-2015)

Evidence from Fig. 7 and Table 2 shows that five land use types were identified in this eco-region. These land use include forest, settlement, Plantation \& farmland, mangrove and low vegetation (savana \& prairie). Their mutation over time was studied and the corresponding result presented in a tabular manner. It is very clear that these land use have changed over space and time. The natural forest landscape has been unrest as man continues to rape huge portions of land for his economic gains without making any commensurate efforts to their sustainability.

The surface occupation of this region shows dynamism of land use types changing as years goes by from 1978 to 2000 and finally 2015 (Fig. 8).

The major threats to forest landscapes in the Mount Cameroon forest region are defined in terms of insufficiently protected areas, excess poaching, poor law enforcement, land encroachment, unsustainable methods of exploiting forest resources, poor methods of agriculture and illegal logging. 
Land use change in the mount Cameroon eco-region

Table 2 (1978, $2000 \& 2015)$

\begin{tabular}{|l|c|c|c|}
\hline \multicolumn{1}{|c|}{ Land use types } & $\begin{array}{c}\text { Surface area 1978 } \\
\text { in } \mathbf{~ k m}^{\mathbf{2}}\end{array}$ & $\begin{array}{c}\text { Surface area 2000 } \\
\text { in } \mathbf{~ k m}^{\mathbf{2}}\end{array}$ & $\begin{array}{c}\text { Surface area 2015 } \\
\text { in }_{\mathbf{~ k m}}\end{array}$ \\
\hline Forest & 1950.5 & 1718.5 & 1460 \\
\hline Settlement & 37 & 47.8 & 197.8 \\
\hline Plantation \& farmland & 1143.2 & 1430.15 & 1730 \\
\hline Mangrove & 1122.04 & 915.1 & 1198.06 \\
\hline Low vegetation (savanna \& prairie) & 747.26 & 888.45 & 5000 \\
\hline Total & 5000 & 5000 & 5 \\
\hline
\end{tabular}

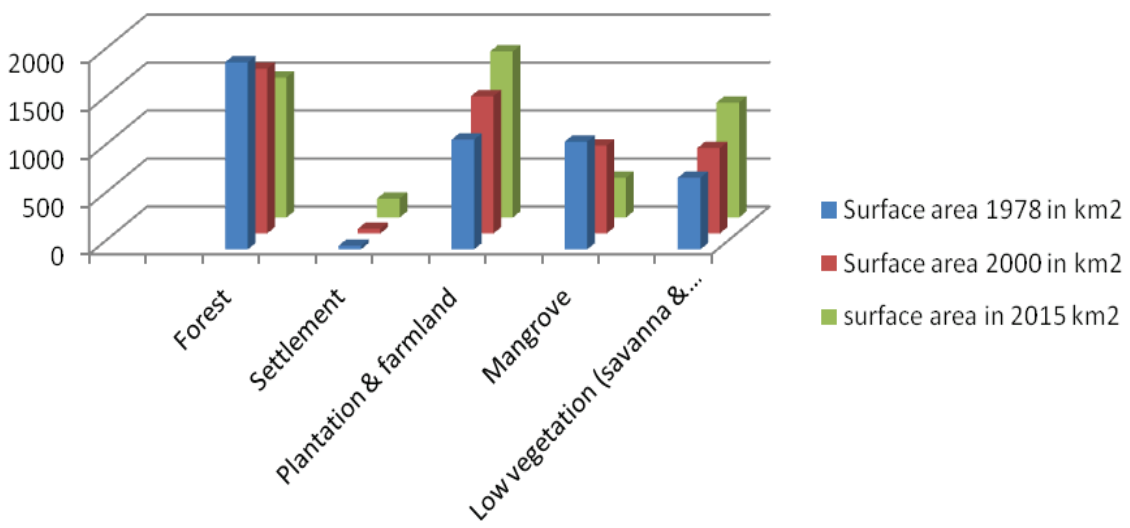

Fig. 8. Land use dynamics in the mount Cameroon eco-region

The fundamental threats lie beyond protected areas in sectors such as agriculture, pollution, settlement patterns and other factors relating to the Mount Cameroon regional economy. It is now very clear that the mount Cameroon eco-region is facing the highest rate of forest loss. The rich volcanic soil that surrounds the foot hills and slopes of the mountain has attracted a high population of immigrants from other parts of the country to settle for agricultural purposes. It is for this reason that the local populations do not respect protected areas. The forest reserves that are found in this area are considered as a free for all property from the bounty of nature. This paper has viewed surface occupation with the use of satellite images and their results have been analyzed in details. 
Evidence from the surface occupation diagrams of 1978, the year 2000 and 2015 shows that, there is a continuous reduction in the forest cover. This reduction is clearly epitomized in the bar chart in (Fig. 8).

In 1978 forest covered $39 \%$ of the territory while in the 2000 it occupied $34 \%$ and in 2015 it occupied $29 \%$. This indicates a drastic reduction in forest cover.

While forest is reducing we noticed an increase in low vegetation (savanna \& prairie). In 1978 low vegetation occupied $15 \%$ and in the year 2000 it occupied $18 \%$ and in 2015 it occupied $29 \%$. This is proof of forest disappearance. When forest is cleared low vegetation automatically occupies the cleared surface.

As concerns settlement, in 1978 we noticed $1 \%$ of settlement, in 2000 we had $1 \%$ and in 2015 we witnessed a sharp increase to $4 \%$. This is proof of a spontaneous urban growth.

In line to plantation and farm land, mount Cameroon remains the agricultural cornucopia or better stills the bread basket of the South West region. In 1978 plantation and farmlands occupied $23 \%$ of the territory and in the year 2000 they occupied $19 \%$ and $35 \%$ in the year 2015. Plantation and farmlands have been in a steady rise thanks to the fertile volcanic soil and an exploding rate of immigrants from other regions who come to look for greener pastures.

As concerns mangrove, this is a very fragile and unstable landscape. In 1978 mangroves covered $22 \%$ of the territory, in the year 2000 they occupied $18 \%$ and in 2015 they occupied only $8 \%$ of the territory. This shows a high rate of exploitation in the mangrove zone. The mangroves have reduced drastically, almost 3 times from its original size.

As concerns the slopes of mount Cameroon, the Eastern slopes of are more affected than the Western slopes. As viewed from satellite projections in Fig. 5 \& 6, large arches of land are been converted into agro-industrial plantations growing tea, rubber and palms. Coupled with the high rate of urbanization witnessed within this years, there is a spontaneous increase in residential infrastructures. The high cost of land within the city center have pushed many city dwellers to construct on very steep slopes which are exposed to natural hazards like land slide and soil creep most especially at the heart of the rainy season. The over increasing population growth rate from immigrants who come to look for greener pastures as a result of fertile volcanic rocks and employment opportunities offered by the numerous Cameroon Development Corporation (CDC) have only help in mounting pressure on the already depleted forest resources.

The western slopes remain untouched. It is in this area that we have natural forest. The slopes are much closed to the Atlantic Ocean with very difficult terrain. This natural advantage makes it difficult for the forest-adjacent communities to invade. Here, we have a series of protected areas with the Mount Cameroon Project (MCP) as the biggest. Other international projects like the REDD (Reduced Emissions from Deforestation and Forest Degradation) have been initiated in the area to protect the forest and its resources from continuous depletion. 


\section{CONCLUSION}

Forest degradation in the Mount Cameroon eco-region can be explained by the combination of physical and socio-economic factors. But the role played by human comes to the forefront. This eco-region has lost closed to $79 \%$ of its natural forest by the year 2015. If this barbaric rape of the forest landscapes continue without abatement, it is very clear that by the year 2040 forest will become history.

Taking into consideration the importance of mountanious regions as concern resource base for endermic species, it becomes vital for policy makers to implement adaptive environmental strategies for the sustainable management of this eco-region. Thus the author therefore, proposes a Participatory forest management approach through the involvement of the forest-adjacent communities as the best method to protect, conserve and to rationally use forest resources in this region. Taking cognizant of the fact that the forest-adjacent communities argue the state has created forest reserves on their land, it is obvious that a participatory forest management approach will give them a sense of ownership of the resources. This will give them the courage and hope to protect and conserve the forest.

The success of this approach depends on the establishment of genuine partnerships for sustainable management of forest resources between the state forestry departments and the forest-adjacent communities. Participation leads to incorporation of new kinds of information in environmental decision-making, and shifts the responsibility of environmental conservation from the state to the forest-adjacent communities. Therefore, any forest management plans in the Mount Cameroon eco-region that does not carter for the needs of the forest-adjacent communities who solely depend on the exploitation of forest resources for their livelihood is bound to fail.

\section{REFERENCES}

1. Alongi, D. M. (2002), Present state and future of the world's Mangrove forests. Environ Conserv, vol. 29, pp. 331-349.

2. Alongi, D. M. (2008), Mangrove forests: Resilience, protection from tsunamis, and responses to global climate change, Estuarine, Coastal and Shelf Science. Environ Conserv, vol. 76, pp. 1-13.

3. Balgah, S. N. (2001), Exploitation and Conservation of Biological Resources in the Mount Cameroon Region, Cameroon. Africa Journal of Social Sciences Readings in Geography, Bamenda, pp. 310-324.

4. Balgah, S. N. (2005), Land use and Land Cover Dynamics in the Buea and Tiko Sub-Divisions, Unpublished Univer. Buea, pp. 105-115.

5. Bokwe, A. (1994), Rapport de la mission Effectuée Autour du Mont-Cameroun (Province du Sud Ouest) relatif à la régénération de certaines espèces des produits forestières secondaires en voie de disparition. Ministère de l'Environnement et Foret, Cameroun, AFRIKA FOCUS, vol. 27, pp. 21-28.

6. Bokwe, S. N. (2008), Land use practice in Mbonge Forest Communities. Unpublished Master Thesis, Buea, University of Buea, pp. 64-85.

7. Bokwe, S. N. (2013), Adapting forest governance to climate Change mitigation and poverty alleviation, the case of forest reserves in the Mount Cameroon region. Unpublished Ph.D Thesis, Buea, University of Buea, pp. 170-174.

8. FAO \& JRC. (2012), Global forest land-use change 1990-2005, Food and Agriculture Organization of the United Nations and European Commission Joint Research Centre, No. 169. Rome, pp. 26-28.

9. Gartlan, J. S. (1989), La conservation des ecosystemes forestiers du Cameroun. IUCN, Gland Switzerland \& Cambridge, United Kingdom, pp. 30-57. 
10. Gorshkov, V. G. (2000), Environmental Safety, Climate Stability and the non-perturbed biota. In Global Change News Letter (IGBP), No. 43, pp. 24-25.

11. IUCN. (1988), International Union for the Conservation of Nature Red list of threatened animals. MCN, Gland, Switzerland, pp. 1-6.

12. Jeffrey, A. (1989), Conserving the Worlds Biological Resources. IUCN/World Bank, Washington D.C, pp. 17-20.

13. Kah, E. F. (2000), Contribution of remote sensing in the evaluation of forest dynamics along the slopes of Moun Cameroon. University of Yaounde I, Yaounde, pp. 1-38

14. Lambi, C. M. (2012), Land use Dynamics on the Eastern slopes of Mount Cameroon. African Journal of Socia Sciences, Buea, vol. 7. No. 3, pp. 11-18.

15. Lambi, C. M. (2016), Man and the Changing Forest Landscape in Fako Division. African Journal of Social Sciences, Buea, vol. 1, No. 3, pp. 21

16. Letouzey, R. (1968), Etude phytogéographique du Cameroun. Paris, France, pp. 1-15.

17. Letouzey, R. (1985), Notice de la carte phytogeagraphique du Cameroun au 1:500,000. Document T-V. Institut de la Carte Internationale de la Végétation, Toulouse, France, 17 p.

18. Mbella, M. F. (2011), Urban Development in Fako Division. Unpublished Master's Thesis, University of Buea, pp. $120-150$.

19. MCP. (1998), The Elaboration of a Sustainable Structure for Management and Conservation of the Natural Resources in the MCP Region, Buea, pp. 93-95.

20. Ministry of Forestry and Wildlife and World Resources Institute (2007), Interactive Forestry Atlas of Cameroon, vers. 2, Yaounde, 2007, pp. 3-9.

21. Mukete, N. M. T (2016), Community conflicts over forest resources in the Southern Bakundu Forest Reserve. International Journal of Resource and Environmental Management, Buea, vol. 1. No 1, pp. 69-80.

22. Mukete, N. M.T. (2016), Non-Timber Forest Products (NTFPs) Exploitation and Forest Conservation in the Fako-Meme Divisions of Cameroon. Nova Science Publishers, New York, USA, pp. 29-53.

23. Mukete, N M. T. (2016), Soil cover and agricultural land-use in the Fako-Meme region, Cameroon. Newsletter of Odessa National University, Geography-Geological Science, Odessa, vol. 22. - No 2 (29), pp. 96-106.

24. Mukete, N. M. T. (2017), Modern threats to Forest Landscapes: the case of oil palm cultivation in the South West Region of Cameroon. Newsletter of Odessa National University, Geography-Geological Science, Odessa, vol. 22. No 1 (30), pp. 60-78.

25. Mukete, N. M. T. (2017), Fuel wood exploitation and its implications in the Fako-Meme Region of Cameroon Scientific Journal of Vinnitsa State Pedagogical University, Geographical series, Vinnitsa, vol. 29. No 1-2, pp. 140-147.

26. Ndenecho, E. N. (2007), Investigating the livelihoods of forest-adjacent communities in forest conservation projects: Case study of Mount Oku, Cameroon Journal of Applied Social Sciences, University of Buea. vol. 6. No. $1 \& 2$, pp. 57-63.

27. Nganjo, R. N. (2016), The Effects of Deforestation on Tropical Montane Forest on Drinking Water Supply in Ndu Sub-Division, North West Region of Cameroon. International Journal of Resource and Environmental Management. vol. 1. No. 1, pp. 53-68.

28. Njabe, R. (2013), Urban land use change in Kumba Municipality. Unpublished Ph. D Thesis Buea: University of Buea, pp. 102-146.

29. Njome, M. S. (2007), Structural and Petrochemical Evolution of the Mount Cameroon Volcano, West Africa Upublished PhD Thesis University of Buea, Pg. 135, pp, 1-11.

30. Robiglio, V. (2008), Beyond slash and burn landscape Ecology of Shifitng Cultivation Systems in Southern Cameroon. SENR Bangor, University of Wales. vol. 2. No. 2, pp. 35-37.

Надійшла 01. 05. 2019 
Теофілус Мукете Найомбе Мото, здобувач (Камерун)

Одеський національний університет імені I. І. Мечникова, кафедра фізичної географії та природокористування, пров. Шампанський, 2, Одеса, 65058, Україна muketem2002@yahoo.com

\title{
СУЧАСНІ ЗАГРОЗИ, ЯКІ ВПЛИВАЮТЬ НА ПРИРОДНИЙ СТАН ЛІСОВИХ ЛАНДШАФТІВ У ПІВДЕННО-ЗАХІДНІЙ ЧАСТИНІ КАМЕРУНУ (НА ПРИКЛАДІ ГОРИ КАМЕРУН)
}

\begin{abstract}
Резюме
У статті розглянуті природні та антропогенні чинники, які вплинули на швидке збезлісення та руйнування лісових ландшафтів екосистеми гори Камерун. Результати дослідження показали, що поєднання природно-антропогенних чинників призвело до зменшення площі лісових ландшафтів даного екорегіону до 79\%. Причиною цього слугувало нераціональне використання місцевим населенням природних ресурсів заради своїх корисливих економічних вигод, не роблячи при цьому ніяких дій для їх стійкості та збереження. Найбільш поширеними загрозами в даному регіоні є агресивні методи ведення сільського господарства й розширення агропромислових плантацій, виверження вулкана та як наслідок пожежі на сільськогосподарських угіддях, неконтрольоване використання деревини (збір дрів та будівельних матеріалів) і т.д. Все це призвело до втрати біорізноманіття, зменшення потоків води в струмках і річках, а також до зниження якості «зеленого» туризму та забезпечення місцевого населення життєво важливими ресурсами в умовах постійного зростання населення.

На основі польових i дистанційних методів дослідження нами була проаналізована вертикальна структура природних лісових ландшафтів гори Камерун (мангрові ліси, рівнини/пішохідні пагорби та гірські/афромонтанні лісові ландшафти). Також, вивчена їх динаміка й трансформація у продовж останніх 50 років (1965-2015 рр.) На основі супутникових знімків трьох найбільш показових часових періодів - 1978, 2000 і 2015 років.

Розроблено адаптивні стратегії раціонального управління лісовими ресурсами та запропоновано деякі невідкладні природоохоронні стратегії для порятунку природних лісових ландшафтів в еко-регіоні Камеруну. Запропонований автором підхід, заснований на залученні до управління лісами суміжних 3 даним регіоном спільнот як кращий метод раціонального використання, захисту та збереження лісових ресурсів в цьому регіоні.
\end{abstract}

Ключові слова: природні лісові ландшафти, гора Камерун, південно-західний регіон, Камерун. 
Теофилус Мукете Найомбе Мото, соискатель (Камерун)

Одесский национальный университет имени И. И. Мечникова, кафедра физической географии и природопользования, пер. Шампанский, 2, Одесса, 65058, Украина, muketem2002@yahoo.com

\title{
СОВРЕМЕННЫЕ УГРОЗЫ, ВЛИЯЮЩИЕ НА ПРИРОДНОЕ СОСТОЯНИЕ ЛЕСНЫХ ЛАНДШАФТОВ В ЮГО-ЗАПАДНОЙ ЧАСТИ КАМЕРУНА (НА ПРИМЕРЕ ГОРЫ КАМЕРУН)
}

\begin{abstract}
Резюме
В статье рассмотрены природные и антропогенные факторы, которые повлияли на быстрое обезлесение и деградацию лесных ландшафтов экосистемы горы Камерун. Результаты исследования показали, что сочетание природно-антропогенных факторов привело к уменьшению площади лесных ландшафтов данного экорегиона до 79\%. Причиной этого послужило нерациональное использование местным населением природных ресурсов ради своих корыстных экономических выгод, не предпринимая при этом никаких действий для их устойчивости и сохранения. Наиболее распространенными угрозами в данном регионе являются агрессивные методы ведения сельского хозяйства и расширение агропромышленных плантаций, извержение вулкана и как следствие пожары на сельскохозяйственных угодьях, не контролированное использование древесины (сбор дров и строительных материалов) и т.д. Всё это привело к утрате биоразнообразия, уменьшению потоков воды в ручьях и реках, а также к снижению качества «зеленого» туризма и обеспечения местного населения жизненно важными ресурсами в условиях постоянного роста населения.

На основе полевых и дистанционных методов исследования нами была проанализирована вертикальная структура природных лесных ландшафтов горы Камерун (мангровые леса, равнины/пешеходные холмы и горные/афромонтанные лесные ландшафты). Также, изучена их динамика и трансформация в течении последних 50 лет (1965-2015 гг.) на основе спутниковых снимков трёх наиболее показательных временных периодов - 1978, 2000 и 2015 годов.

Разработаны адаптивные стратегии рационального управления лесными ресурсами и предложены некоторые неотложные природоохранные стратегии для спасения природных лесных ландшафтов в эко-регионе Камерун. Предложенный автором подход, основанный на привлечении к управлению лесами смежных с данным регионом сообществ как лучший метод рационального использования, защиты и сохранения лесных ресурсов в этом регионе.
\end{abstract}

Ключевые слова: природные лесные ландшафты, гора Камерун, юго-западный регион, Камерун. 